\title{
In the Eyes of Turkish EFL Learners: What Makes an Effective Foreign Language Teacher?
}

\author{
Servet Çelik \\ Karadeniz Technical University (Turkey) \\ Arda Arikan and Mustafa Caner \\ Akdeniz University (Turkey)
}

Received: 4 May 2012 / Accepted: 28 September 2012

ISSN: $1697-7467$

\begin{abstract}
Research on the qualities of successful teachers in Turkey indicates that students consider teacher effectiveness as the ability to ensure an environment in which positive student-teacher interaction can take place. However, further studies are needed to clarify students' perceptions of the qualities of effective foreign language teachers, in particular, thus providing educators with necessary information concerning the implementation of language teacher development programs. Therefore, 998 undergraduate students at a state university in Turkey were asked to complete a survey concerning the qualities they believed are characteristic of a successful English language teacher. The results provide a detailed profile of university English as a foreign language (EFL) students' perceptions with respect to pedagogy-specific knowledge, personality traits, professional skills and classroom behavior.
\end{abstract}

Keywords: Effective, EFL, language teacher, foreign language, teacher qualities

A través de los ojos de estudiantes de inglés como lengua extranjera en Turquía: ¿Qué hace a un profesor de lengua extranjera efectivo?

RESUMEN: Investigaciones sobre las cualidades de profesores con éxito en Turquía indican que los estudiantes consideran la eficacia del profesor como la capacidad para garantizar un entorno en el que se pueda desarrollar una interacción profesor-estudiante positiva. No obstante, son necesarios más estudios para poder clarificar la percepción que tienen los estudiantes sobre las cualidades de los profesores eficaces de lengua extranjera. El objetivo de estos estudios es el de proveer a los educadores con la información necesaria sobre la implementación de programas para el desarrollo de profesores de lenguas. Con este propósito, 998 estudiantes de una universidad estatal en Turquía participaron en una encuesta para determinar cuáles son las cualidades que ellos creen características en un profesor de inglés con éxito. Los resultados muestran un perfil detallado sobre el Inglés universitario como lengua extranjera y sobre la percepción que los estudiantes tienen respecto a conocimientos específicos pedagógicos, rasgos personales, habilidades profesionales y conducta en el aula.

Palabras clave: efectivo, inglés como lengua extranjera, profesor de idiomas, lengua extranjera, cualidades del profesor 


\section{INTRODUCTION}

Teacher effectiveness has been an ongoing topic of interest among educational researchers for many years, with considerable focus given to the specific traits and behaviors that are believed to constitute effective teaching. Hativa, Barak, and Simhi (2001) point out that teacher effectiveness is not merely about fitting a particular teacher type or conforming to a set of external criteria; rather, it involves understanding what being a good teacher really means and incorporating classroom practices that are appropriate for the wider social context. Accordingly, Anderson, Evertson, and Brophy (1979: 193) described effective teaching as "what teachers do in the classroom" in terms of "what happens to their students", referring to the 'process' and the 'product' approaches to learning respectively. Whether the emphasis is on the process or the product, defining effective practice is not a simple matter, in part because there are numerous external factors which affect teaching outcomes. These may include school-related issues (Anderson, Evertson and Brophy, 1979) and other circumstances which are beyond teachers' control (Brosh, 1996). However, Bell (2005: 259) asserts that the qualities of an effective teacher can, in fact, be identified. As she explains, although "there is little agreement regarding which specific behaviors constitute effective teaching, researchers agree at least on some dimensions" that exemplify the characteristics of effective classroom instructors. For instance, numerous scholars have argued that the most successful teachers are enthusiastic about their teaching (Cheung, 2006; Feldman, 1986; Murray, 1991, 1997), have a positive regard for and rapport with their students (Dunkin, 1995; Lowman, 1996; Murray, 1991), organize their course content to meet their learners' needs and interests (Feldman, 1986; Young and Shaw, 1999) and provide a comfortable atmosphere that motivates students to learn (Cheung, 2006). Similarly, Feldman (1986) points to warmth and kindness as important qualities for an effective teacher. After reviewing several theoretical and experimental studies, Hunt (2009: 1) offered a generalized definition of teacher effectiveness as:

The collection of characteristics, competencies, and behaviors of teachers at all educational levels that enable students to reach desired outcomes, which may include the attainment of specific learning objectives as well as broader goals such as being able to solve problems, think critically, work collaboratively, and become effective citizens.

In the context of foreign language instruction, classroom instructors are often the only speakers with whom students have the opportunity to interact in the process of developing their language skills; thus, the effectiveness of foreign language teachers is seen as especially critical. Accordingly, a number of researchers have attempted to delineate the traits of exemplary foreign language teachers (Schulz, 2000), focusing on both the teaching practice and the personal attributes of successful classroom instructors. In terms of methods and approaches used, for instance, Brown (2009) found that American students favored a grammar-based approach, whereas their teachers preferred a more communicative classroom. This suggests that teachers and students may hold different perceptions and expectations with respect to the characteristics of an effective foreign language teacher. This theory is supported by Park and Lee (2006); their research revealed that, while English language teachers in Korea ranked pedagogical knowledge as more important than English language 
proficiency, Korean EFL students prioritized teachers' English skills over their instructional approach and socio-affective characteristics.

Additional studies concerning the characteristics of effective English language teachers have been carried out in a variety of contexts. For example, Shishavan and Sadeghi (2009), in their examination of the opinions of English language teachers and learners, found that English language teachers believed that preparing lessons well, using appropriate lesson plans and assessing what students have learned in a reasonable fashion are most important. On the other hand, the students who participated in the study expressed that the ability to teach English using the learners' mother tongue was the leading quality of an effective language teacher. Furthermore, while mastery of the target language, having accurate pedagogical knowledge, and being able to use specified techniques and methods were important for the teachers, the students opted for a teacher's positive personality.

In a similar study carried out in Iran, Ghasemi and Hashemi (2011) investigated students' views of the characteristics of effective English language teachers under three main categories, including subject matter knowledge, pedagogical knowledge, and socio-affective skills. According to their findings, certain teacher characteristics such as reading and speaking proficiency; ability to arouse students' interest in learning English; and building students' self-confidence and motivation were seen as universally desirable. Moreover, many of their participants emphasized listening ability and grammatical proficiency as especially important. In the Thai context, Wichadee (2010) explored the qualities of effective English language teachers based on the four categories of (1) English proficiency, (2) pedagogical knowledge, (3) organization and communication skills, and (4) socio-affective skills. The results of their investigation suggested that teachers' organization and communication skills were of greatest significance to students. In contrast, the teachers surveyed in their study ranked English proficiency as the most important quality in effective language teaching. On the other hand, Chen and Lin (2009) found that junior high school students in China generally perceived teachers' personality and teacher-student relationships to be more important than their instructional competence; the teachers surveyed similarly believed that being enthusiastic, friendly, open-minded, respectful, and caring were the leading characteristics of effective English language teachers.

In Turkey, where a great deal of attention is focused on English language instruction (Büyükkantarcıŏglu, 2004; Çelik, 2011, 2012; Doğançay-Aktuna and Kızıltepe, 2005; Kızıldağ, 2009), the effectiveness of English teachers has received particular attention. While research indicates that the majority of Turkish students perceive teacher efficacy in general as the ability to ensure a comfortable learning environment in which positive student-teacher interaction takes place (Saraç-Süzer, 2007; Telli, den Brok and Çakıroğlu, 2008), a variety of studies point to specific characteristics as being necessary for English as a Foreign Language (EFL) instructors. For instance, Korkmaz and Yavuz (2011) demonstrate that prospective teachers view fairness, knowledge of how to teach efficiently, ability to motivate students and skill in applying various teaching methods as important qualities for EFL teachers. On the other hand, knowing how to promote harmonious relationships, communicate with parents, and act as a leader in society were given the least significance. Similarly, a study by Arikan, Taşer and Saraç-Süzer (2008) revealed that university-level students characterize an effective foreign language teacher as a friendly, non-native speaker of English who is fluent in the English language and who is young; while little emphasis was placed on the teacher's 
authority in the classroom. In addition, their study showed that students ranked foreign language teachers' personal qualities such as enthusiasm, creativity, and fairness in their decisions as more important than pedagogical skills, including error correction techniques, use of technology, ability to teach language skills and classroom management. These results are consistent with Taşkafa's (1989) findings, which indicated that providing students with positive reinforcement and being friendly were the most desirable qualities for an effective foreign language teacher.

In another study conducted in the Turkish context, Çubukçu (2010) found that successful teachers must embrace the ideal of caring about students and their learning. In addition, language instructors must have the ability to use a variety of instructional methods in their classrooms, create a relaxing environment, and adapt to the needs of students regarding language learning motivation and interests. Finally, although not directly related to the field of English language teaching, a study conducted by Yilmaz (2011) explored the perceptions of pre-service teachers enrolled in various majors at a Turkish university. His findings revealed that the majority of the participants expressed preference for warm, kind, sincere, friendly, sociable and familiar teachers who were enthusiastic, excited about teaching, dynamic, and motivating.

\section{Purpose of the study}

In order to achieve successful learner outcomes in foreign language teaching, it is essential that teachers and teacher educators obtain a clear understanding of what learners perceive as an effective classroom instructor. However, in much of the literature outlined above, it can be noted that the attributes cited by students as characteristic of effective teachers were often at odds with the qualities that the teachers themselves found to be most important. Thus, the researchers in this case believed that shedding light on the perceptions of learners was especially critical. Accordingly, the present study was conducted in order to establish a profile of the qualities that Turkish EFL learners view as descriptive of an effective foreign language teacher. The results of this and similar studies may be useful in both the practical and the theoretical sense, as they can inform teachers about the specific teaching methods and personal qualities that are considered by students to be most important, allowing them to shape their practice in order to better meet the needs of learners. In addition, the findings may assist administrators and educational policy makers in formulating decisions concerning curriculum design and teacher development programs.

\section{Methodology}

Because the researchers were interested in presenting a substantive view of the qualities of an effective foreign language teacher, a quantitative research design was adopted. Accordingly, the researchers applied a survey which was designed to rate the participants' perceptions based on the importance they placed on specific characteristics of EFL instructors. 


\subsection{Setting and Participants}

The participants in the study were 998 undergraduate students who were enrolled at a state university in Turkey at the time of data collection. All of the students had taken EFL courses for more than 10 years, beginning in the fourth grade in elementary school and continuing through the university level. Among the participants, 156 were preparatory school students in an intensive English language course, 254 were freshmen, 206 were sophomores, 240 were juniors and 142 were seniors. No further demographic information was collected, as the researchers did not intend to correlate students' responses to their personal or demographic qualities. As the researchers in this case needed a fast, inexpensive, and easy way to recruit participants, convenience sampling (Creswell, 2007; Miles and Huberman, 1994) was employed; accordingly, students who were easily accessible to one of the researchers were selected to participate in this study. This method may raise concerns with regard to bias, as arbitrarily selecting participants does not guarantee a representative cross-sample of the study population (Skowronek and Duerr, 2009). However, in this case, the large sample size was believed to be sufficient to compensate for this issue.

\subsection{Data Collection and Analysis}

The data were collected via a Likert-type scale that was adapted from existing surveys developed by Yu-Hsin (1999) and Arikan, Taşer and Saraç-Süzer (2008). Each item in the survey was constructed to refer to a segment of the knowledge and interactive practice described in Bell's (2005: 260) definition of an effective teacher; namely, one who "provides learners with the grammatical (syntactical and morphological), lexical, phonological, pragmatic, and sociocultural knowledge and interactive practice they need to communicate successfully in the target language".

The survey included 37 items, with options to rate each item on a scale from 1 (not important at all) to 5 (very important) in order to show the extent to which each item represented the quality or behavior of an effective foreign language teacher. In order to ensure that the questionnaire items accurately measured what they were intended to measure, and that the format of the questions and the interaction between them would not skew the results (Golafshani, 2003), an expert in the field who was not involved with the study was asked to review the survey, and revisions were made to the items based on the observations made by the external judge (Fraenkel and Wallen, 2008). Furthermore, testing of the internal consistency of the scale revealed a reliability coefficient of 0.85 , which indicates that the scale can be considered as a reliable data collection tool for the purposes of this study.

Data collection took place over a three-month period during the 2010-2011 academic year. Before completing the questionnaire, the participants were informed of the purpose of the study, and informed consent was obtained. The quantitative data obtained from the scale were analyzed using descriptive statistics; the means, standard errors and deviations of each of the items interrogated were calculated using SPSS software. 


\section{Results}

Although the items in the surveys were presented at random, they have been categorized here according to the teacher characteristics identified for the purposes of this study. The results for each category are listed in order of the importance attributed by the participants to each of the qualities $(\mathrm{M}=$ Mean, $\mathrm{SE}=$ Standard Error and $\mathrm{SD}=$ Standard Deviation $)$. Table 1 presents the results concerning teachers' personalities, while the results indicated in Table 2 delineate the qualities and skills that are specific to foreign language teaching; these include such features as grammatical, lexical, phonological, pragmatic, and sociocultural knowledge, as well as the ability to provide the interactive practice that students require in order to become successful speakers of the target language. The items in Table 3 represent those professional skills and classroom behaviors that are expected from all teachers.

As shown in Table 1, the highest scores were attached to the attributes of being fair and just (3.74), as well as to showing enthusiasm (3.72). These were followed by personal qualities such as friendliness (3.49), being loving (3.47), creativity (3.46), and being experienced (3.17). In addition, being humorous (3.08) and being Turkish, but good in English (3.05) were reported as being important characteristics of an effective foreign language teacher. The least significant items included being young (2.00), having lived in a foreign country (1.95), being a native speaker of English (1.57) and being a male or a female (1.40).

Table 1. Personal Qualities and Personality Traits (from high to low).

\begin{tabular}{llll}
\hline Items & $M$ & $S E$ & $S D$ \\
1. Fair and just & 3.74 & .01673 & .528 \\
2. Enthusiastic & 3.72 & .01769 & .558 \\
3. Friendly & 3.49 & .02158 & .681 \\
4. Loving & 3.47 & .02091 & .660 \\
5. Creative & 3.46 & .02210 & .698 \\
6. Experienced & 3.17 & .02693 & .850 \\
7. Humorous & 3.08 & .02618 & .827 \\
8. Turkish, but good in English & 3.05 & .03220 & 1.01 \\
9. Turkish and good in target culture & 2.93 & .03084 & .974 \\
10. Young & 2.00 & .03349 & 1.05 \\
11. Has lived in a foreign culture or country & 1.95 & .03352 & 1.05 \\
12. Native speaker of English & 1.57 & .02789 & .881 \\
13. Gender & 1.40 & .02738 & .864 \\
Mean 2.84 & & & \\
\hline
\end{tabular}

Certain items that dealt with teachers' pedagogical skills and content knowledge were also observed to be important, as can be seen in Table 2. Teaching pronunciation (3.68) and speaking well (3.68) were two of the most highly ranked items in this category, indicating that these skills were among the most significant to the participants. These were followed by the ability to teach reading skills adequately (3.64) and to provide explanations in Turkish (3.63). Teaching writing (3.59) and listening (3.48) skills adequately were also perceived as significant, as well as the ability to explain grammatical rules sufficiently (3.45). Using literary texts in the classroom received the lowest score in this segment of the survey (2.79). 
Table 2. Content and Pedagogy-Specific Knowledge (from high to low).

\begin{tabular}{llll}
\hline Items & $M$ & $S E$ & $S D$ \\
1. Teaches pronunciation well & 3.68 & .01680 & .530 \\
2. Teaches speaking skills adequately & 3.68 & .01718 & .542 \\
3. Teaches reading skills adequately & 3.64 & .01732 & .547 \\
4. Teaches writing skills adequately & 3.59 & .01921 & .606 \\
5. Teaches listening skills adequately & 3.48 & .02227 & .703 \\
6. Explains grammar rules well & 3.45 & .02205 & .696 \\
7. Gives real-life examples while teaching & 3.44 & .02215 & .699 \\
8. Teaches both academic and daily language & 3.40 & .02402 & .758 \\
9. Teaches the target culture adequately & 3.28 & .02567 & .810 \\
10. Helps students to learn the language easily & 3.26 & .02518 & .795 \\
11. Uses literary texts in the classroom & 2.79 & .03390 & 1.07 \\
Mean $=3.44$ & & & \\
\hline
\end{tabular}

Furthermore, Table 3 demonstrates that having a sound knowledge of vocabulary (3.68) and grammar (3.63) were also closely associated with teacher effectiveness, along with the ability to reduce students' anxiety (3.58) and being good at classroom management (3.56). Incorporating technology and visual materials (3.33) into the classroom was also considered a leading quality of an effective foreign language teacher. On the other hand, it can be seen that among the professional skills and classroom behaviors surveyed, the least important qualities were found to be giving assignments regularly (2.07), acting as the only authority in the classroom (2.03) and speaking rather than listening to students (1.76).

Table 3. Professional Skills and Classroom Behavior (from high to low).

\begin{tabular}{llll}
\hline Items & $M$ & $S E$ & $S D$ \\
1. Has sound knowledge of vocabulary & 3.68 & .01743 & .550 \\
2. Has sound knowledge of grammar & 3.63 & .01913 & .604 \\
3. Reduces students' anxiety & 3.58 & .01896 & .599 \\
4. Good at classroom management & 3.56 & .01857 & .586 \\
5. Uses technology and visual materials well & 3.33 & .02220 & .701 \\
6. Takes attendance & 2.62 & .03290 & 1.03 \\
7. Regularly gives tests and quizes & 2.58 & .03040 & .960 \\
8. Plays games during teaching & 2.50 & .03263 & 1.03 \\
9. Asks students to check on each other's work & 2.35 & .03150 & .995 \\
10. Gives assignments regularly & 2.07 & .02951 & .932 \\
11. Acts as the only authority in the classroom & 2.03 & .03351 & 1.05 \\
12. Speaks rather than listening to students & 1.76 & .03072 & .970 \\
Mean $=2.80$ & & & \\
\hline
\end{tabular}

\section{Discussion AND CONClusion}

A review of the survey results provides a detailed picture of how university-level Turkish students perceive an effective English language teacher, drawing from their views of the importance of pedagogical and content knowledge, personality traits, professional skills and classroom behavior. Specifically, the results of the present study support the findings of previous researchers who contend that students perceive a successful teacher to be fair 
and just (Korkmaz and Yavuz, 2011) and to demonstrate enthusiasm for teaching (Cheung, 2006; Feldman, 1986; Murray, 1991, 1997). Similarly, the current findings, which indicate that an effective language teacher is successful in reducing students' anxiety while being skilled at classroom management, support the view that providing a comfortable learning atmosphere (Chen \& Lin, 2009; Cheung, 2006; Çubukcu, 2010; Ghasemi and Hashemi, 2011; Saraç-Süzer, 2007; Taşkafa, 1989; Telli, den Brok and Çakıroğlu, 2008; Wichadee, 2010) and treating students with warmth and kindness (Feldman, 1986; Y1lmaz, 2011) are considered as important characteristics for an effective foreign language teacher.

The results in this case also reveal that Turkish students expect their teachers to have a sound knowledge of vocabulary and grammar; this is supported by Park and Lee's (2006) finding that students prioritize their teachers' proficiency in English over their teaching methods and socio-affective skills. However, Turkish students also place importance on the ability of their teachers to teach pronunciation, speaking and reading skills well. Finally, the analysis of Shishavan and Sadeghi (2009) supports the results of the present study, which indicate that Turkish students find teachers who are adept at providing explanations in the students' mother tongue to be effective.

As the findings of this and previous studies suggest, there appears to be a strong consensus with regard to the importance of content knowledge (vocabulary and grammar) as well as the methods used to teach this knowledge (pronunciation, speaking, reading, and using Turkish to explain difficult matters). Similarly, Turkish students believe that effective teachers should have the ability to reduce students' anxiety in the classroom and make learning the language easy. Items related to the authority of the teacher (Table 3, items 11 and 12) had the lowest score in terms of teacher effectiveness; it can therefore be concluded that Turkish students prefer not to see the teacher as an authority figure, but rather as a friendly and loving individual.

Taking the most prominent qualities noted by the participants into account, the profile of an effective foreign language teacher can be established as one who:

1. exhibits fairness in decision-making;

2. is successful in reducing students' anxiety;

3. demonstrates enthusiasm;

4. teaches pronunciation well;

5. teaches speaking skills adequately;

6. has a sound knowledge of vocabulary;

7. teaches reading skills adequately;

8. has a sound knowledge of grammar;

9. is adept at providing explanations in Turkish (mother tongue);

10. is good at classroom management;

11. teaches writing skills adequately.

It should be noted that this study is limited in the sense that the survey questions comprised open-ended concepts whose definitions and meanings may differ from one individual to another, as characteristics such as being friendly, creative or loving are matters of personal perspective. In addition, as Bell (2005: 267) notes, questionnaire studies "cannot provide a description or explanation of complex and interacting social, cultural, linguistic, 
and cognitive factors relating to behaviors and attitudes of teachers". Thus, more in-depth qualitative studies may be useful in illuminating what these qualities mean to learners. Finally, because this study is limited to the opinions of students attending one specific university, further research which includes students studying at different levels and at different schools might add greater validity to the results obtained.

It is believed that instruction by an effective teacher increases student success, yet evaluation of teaching should not necessarily be confined to the final product of what is an evolving process. Even expert teachers start out as novices, gradually changing their teaching styles to fit their learners' needs and expectations. In this sense, it may be claimed that an effective teacher is always in the process of professional growth; and thus, teacher effectiveness should be perceived as a fluid rather than a fixed phenomenon. Furthermore, research shows that "while teaching behaviors are considered to be effective regardless of discipline, there are also teaching behaviors and attitudes that are considered to be discipline specific" (Bell, 2005: 259). Hence, apart from the teacher characteristics examined in this study, the qualities of instructors within specific fields should be interrogated in future research in order to guide teacher educators in implementing more effective professional development programs.

\section{REFERENCES}

Anderson, L.M., Evertson, C.M. and Brophy, J.E. (1979). "An experimental study of effective teaching in first-grade reading groups", in The Elementary School Journal, 79, 4: 193-223.

Arikan, A., Taşer, D. and Saraç-Süzer, H.S. (2008). "The effective foreign language teacher from the perspectives of Turkish preparatory school students", in Education and Science, 33, 150: 42-51.

Bell, T.R. (2005). "Behaviors and attitudes of effective foreign language teachers: Results of a questionnaire study", in Foreign Language Annals, 38, 2: 259-270.

Brown, A.V. (2009). "Students' and teachers' perceptions of effective foreign language teaching: A comparison of ideals", in The Modern Language Journal, 93, 1: 46-60.

Brosh, H. (1996). "Perceived characteristics of the effective language teacher", in Foreign Language Annals, 29, 2: 125-136.

Büyükkantarcioğlu, N. (2004). "A sociolinguistic analysis of the present dimension of English as a foreign language in Turkey", in International Journal of the Sociology of Language, 165: 33-58.

Chen, Y.-J. and Lin, S.-C. (2009). "Exploring characteristics for effective EFL teachers from the perceptions of junior high school students in Tainan", in STUT Journal of Humanities and Social Sciences, 2: 219-249.

Cheung, H.Y. (2006). "The measurement of teacher efficacy: Hong Kong primary in-service teachers", in Journal of Education for Teaching, 32, 4: 435-451.

Creswell, J.W. (2007). Qualitative Inquiry and Research Design: Choosing Among Five Traditions. Thousand Oaks: Sage.

Çelik, S. (2011). "Characteristics and competencies for teacher educators: Addressing the need for improved professional standards in Turkey", in Australian Journal of Teacher Education, 36, 4: 72-87.

Çelik, S. (2012). "The role of foreign-educated scholars in Turkey's higher education system: 
A narrative study of two English language teacher educators", in Turkish Online Journal of Qualitative Inquiry, 3, 3: 56-70.

Çubukcu, F. (2010). "Student teachers' perceptions of teacher competence and their attributions for success and failure in learning", in The Journal of International Social Research, 3, 10: $213-217$.

Doğançay-Aktuna, S. and Kızlltepe, Z. (2005). "English in Turkey", in World Englishes, 24, 2: 263-265.

Dunkin, M.J. (1995). "Concepts of teaching and teaching excellence in higher education", in Higher Educational Research and Development, 14, 1: 21-33.

Feldman, K.A. (1986). "The perceived instructional effectiveness of college teachers as related to their personality and attitudinal characteristics: A review and synthesis", in Journal of Higher Education, 24: 139-213.

Fraenkel, J.R. and Wallen, N.E. (2008). How to Design and Evaluate Research in Education (7th ed.). New York: McGraw Hill.

Ghasemi, B. and Hashemi, M. (2011). "The study of the characteristics of successful English language teachers from the view point of the English language students of Islamic Azad University, Hamedan Branch", in Procedia-Social and Behavioral Sciences, 28: 411-415.

Golafshani, N. (2003). "Understanding reliability and validity in qualitative research", in The Qualitative Report, 8, 4: 597-607.

Hativa, N., Barak, R. and Simhi, E. (2001). "Exemplary university teachers: Knowledge and beliefs regarding effective teacher dimensions and strategies", in Journal of Higher Education, 72, 6: 699-729.

Hunt, B.C. (2009). Teacher Effectiveness: A Review of the International Literature and its Relevance for Improving Education in Latin America (Working Paper No. 43). Washington, DC: Partnership for Educational Revitalization in the Americas.

Kızıldağ, A. (2009). "Teaching English in Turkey: Dialogues with teachers about the challenges in public primary schools", in International Electronic Journal of Elementary Education, 1, 3: 188-201.

Korkmaz, Ş.Ç. and Yavuz, A. (2011). "ELT student teachers' perspectives of an effective English teacher", in Eğitimde Kuram ve Uygulama [Theory and Practice in Education], 7, 2: 207-229.

Lee, J.J. (2010). "The uniqueness of EFL teachers: Perceptions of Japanese learners", in TESOL Journal, 1, 1: 23-48.

Lowman, J. (1996). "Characteristics of exemplary teachers", in New Directions for Teaching and Learning, 65: 33-40.

Miles, M.B. and Huberman, A.M. (1994). Qualitative data analysis: A sourcebook of new methods $\left(2^{\text {nd }}\right.$ ed.). Thousand Oaks: Sage.

Murray, H.G. (1991). "Effective teaching behaviors in the college classroom", in J.C. Smart (ed.), Higher education: Handbook of theory and research (Vol. 6). New York: Agathon, $135-172$.

Murray, H.G. (1997). "Effective teaching behaviors in the college classroom", in R. P. Perry and J.C. Smart (eds.), Effective Teaching in Higher Education: Research and Practice. New York: Agathon, 171-203.

Park, G.P. and Lee, H.W. (2006). "The characteristics of effective English teachers as perceived by high school teachers and students in Korea", in Asia Pacific Education Review, 7, 2: 236-248. 
Saraç-Süzer, S.H. (2007). Examining methodological issues through pedagogical and practicalknowledge of experienced teachers: A case study (Unpublished doctoral dissertation), Hacettepe University, Ankara, Turkey.

Schulz, R.A. (2000). "Foreign language teacher development: MLJ perspectives-1916-1999", in The Modern Language Journal, 84, 4: 495-522.

Shishavan, H.B. and Sadeghi, K. (2009) "Characteristics of an effective English language teacher as perceived by Iranian teachers and learners of English", in English Language Teaching, 2, 4: $130-143$.

Skowronek, D. and Duerr, L. (2009). "The convenience of nonprobability: Survey strategies for small academic libraries", in College \& Research Libraries News, 70, 7: 412-415.

Taşkafa, G. (1989). "As teachers we are evaluating our students constantly: Have you ever thought how our students evaluate us?", in Çă̆daş Ĕ̆itim [Contemporary Education], 14: $27-30$.

Telli, S., den Brok, P. and Çakıroğlu, J. (2008). “Teachers' and students' perceptions of the ideal teacher", in Eğitim ve Bilim [Education and Science], 33, 149: 118-125.

Y1lmaz, A. (2011). "Quality problem in teaching profession: Qualities teacher candidates feel to be required of teachers", in Educational Research and Reviews, 6, 14: 812-823.

Young, S. and Shaw, D. (1999). "Profiles of effective college and university teachers", in Journal of Higher Education, 70, 6: 670-686.

Yu-Hsin, T. (1999). "Examining student perceptions of the ideal language instructor", in Hwa Kang Journal of TEFL, 5: 1-26.

Wichadee, S. (2010). "Defining the effective English language teacher: Students' and teachers' perspectives", in A.M. Stoke (ed.), JALT 2009 Conference Proceedings. Tokyo: JALT. 